\title{
Multi-Dimensional Poverty in Vietnam: New Evidence from Jarai People in the Central Highlands, Vietnam
}

\author{
Nguyen Bang Nong
}

\begin{abstract}
Ethnic minorities in Vietnam account for only $14 \%$ of the total population of Vietnam, but the proportion of poverty accounts for more than $52 \%$ of all poor households in the country. Based on an empirical research, the paper focuses on a specific ethnic minority group, Jarai people. Research results have shown that multidimensional poverty is not easily implemented in the context of changes in natural and social environments. Therefore, multi-dimensional poverty is both theoretical and scientific challenges, and creates obstacles to policy implementation in order to achieve efficiency in Vietnam's commitment to implementing the Millennium Development Goals (MDG) of the United Nations.
\end{abstract}

Key words: Vietnam, Central Highlands, Jarai people, ethnic minorities, multidimensional poverty.

\section{INTRODUCTION}

Vietnam is a multi-ethnic country with 54 ethnic groups. Vietnamese (Kinh) people is majority ethnic group, the remaining ethnic minorities with a population of 13.4 million people, accounting for $14.60 \%$ of the nation's population. Indigenous ethnic minorities in the Central Highlands have a population of 2.47 million people (Phung et al. 2016.)

In the first national survey on poverty in Vietnam in 1992 conducted by the General Statistics Office of Vietnam, the national poverty rate was $58 \%$, in which poor ethnic minorities account for $86 \%$ (Socialist Republic of Vietnam 2002.) Most poor people lived in rural, remote and remote areas. At that time, the Central Highlands region was one of the two regions of the country with the highest poverty rate with $92 \%$ (Baulch et al. 2002.)

Until 2018 , the national poverty rate was only $9.8 \%$, and ethnic minorities accounted for $72 \%$ of the national poverty rate. The poverty rate in the Central Highlands still had only 24.1\% (Pimhidzai 2018.)

According to report of Vietnamese government, Vietnam has achieved many global MDG 2030 including poverty reduction. However, poverty reduction and sustainable development still play an important role in the 2016-2020 Social and Economic Development Plan (SEDP) and the 2011-2020 Social and Economic Development Strategy (SEDS) in Vietnam government. All targets of the global MDG will be fully and further integrated into 2021-2030 SEDS and 2021-2025 SEDP (Prime Minister of Vietnam 2018.)

Revised Manuscript Received on July 22, 2019.

Nguyen Bang Nong, MA (Anthropology), Publications in ethnic minority people in Vietnam.
From 1992 to now, Vietnam has changed concepts and methods of poverty measurement. In 1990s, the concept of poverty in Vietnam was based on basic human needs, and poverty measurement was determined to be poor if the expenditure was below 1.16 million VND per person per year, and was hungry if the amount of Kcal consuming was less than $2.100 \mathrm{Kcal}$ (also known as food poverty.)

From 2015 onwards, Vietnam no longer measured food poverty. The poverty issue is now defined regarding income (under $\$ 30.00$ US and $\$ 38.00$ US per person per month for rural and urban areas) and access to basic social services (education, health, housing, clean water and toilet, and access to information), which was called multidimensional poverty (Prime Minister of Vietnam 2015.) This multidimensional poverty line is also consistent with the criteria of MDG of the United Nations.

Based on the new poverty measurement concept, this paper is to evaluate the multidimensional poverty status of indigenous ethnic minorities in the Central Highlands, Vietnam. This paper also analyses in detail about the Jarai people in Ia Glai community, Gia Lai province of the Central Highlands, Vietnam. The study of the Jarai people shows more specific poverty, and difficulties and challenges in reducing poverty in indigenous ethnic minorities in the Central Highlands. Therefore, this paper argues that sustainable development of indigenous ethnic minorities faces with many barriers by themselves and state's policy. Based on in-depth research in the Jarai community, readers can see the micro-view in the overall picture of poverty and poverty reduction in Vietnam. For the general overview, the paper uses data which are taken from the socio-economic survey of 53 ethnic minorities conducted by the Committee of Ethnic Minorities (Committee for Ethnic Minority Affairs 2016). The specific data of the Jarai people are collected by authors from 2015 until now. In the Ia Glai community, we chose 100 households randomly to do survey by questionnaires. A group of three researchers, including two Jarai people, helped us in doing questionnaires. Furthermore, we did many in-depth interviews and focus groups. Interviewees were women, men, young people, head, and officials of the community. Basically, we combined quantative and qualitative research to dig deeper into history, life and economic activities of Jarai people in this community. The Jarai people is one of indigenous ethnic minorities in the Central Highlands with a population of more than 425,187 people (Nong 2018.) The Jarai people has a unique culture with "king of the water, king of fire" (Dournes 2018), and one of the ethnic groups creating the Gong culture in the Central Highlands that has been recognized by the UNESCO in 2005 .

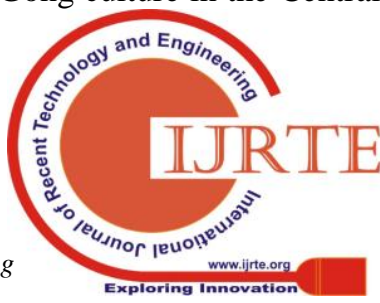




\section{LITERATURE REVIEW}

Research on poverty began in Vietnam in the 1990s. Macro studies on poverty began in 1992 about living standards surveys conducted by the General Statistics Office, United Nations Development Programme (UNDP), Swedish International Development Cooperation Agency (SIDA) and the World Bank in Vietnam.

The first studies of poverty were mainly quantitative analyses based on surveys of living standards. Among them were Living standards during an economic boom: The case of Vietnam edited by Haughton et al. (2001). In this book, the authors compared poverty reduction in Vietnam through two research periods, 1992/1993 and 1997/1998. The research results showed that the poverty reduction rate of Vietnam decreased from $58 \%$ to $37 \%$. The authors argued that the cause of poverty reduction was the shift career from agriculture to non-agriculture sector, or rising rice price. However, the research results also show that poverty remains highly concentrated in rural areas (45\%), and ethnic minorities accounted for $75 \%$ of the total poor households in the country (Haughton 2001).

Baulch et al. in the study on poverty reduction of ethnic minorities in the Central Highlands found that these people had the highest poverty rate in the country. Based on the analytical data, the authors pointed out that the causes of poverty were high due to low education, multiple births, and less access to public health services (Baulch et al. 2002).

Van de Walle and Gunewardena (2001) in their research paper about Sources of ethnic inequality in Vietnam pointed out main effects to poverty ethnic minorities in Vietnam including household size, education, geographic living condition, and owning forest land (Van de Walle and Gunewardena 2001.)

Anh Tuan Bui et al. in the study of poverty of ethnic minorities in Vietnam also said that ethnic minorities had a very high poverty rate compared to the majority (Vietnamese or Kinh people); particular ethnic minorities in the Central Highlands, Vietnam. The poverty rate in this region was even increasing compared to other provinces in the country due to ineffective poverty reduction policies. Since then, policies on socio-economic development created risks of income inequality, widening the gap between the rich and the poor, and those who did not benefit from government development policies (Bui et al. 2017.)

In Indonesia, many ethnic minorities also had the same situations as Vietnamese ethnic minorities. Nooteboom (2015) in the case study on the Madurese people in Indonesia argued that many people even lived below the national poverty line. To copy with the life, many Madurese people relied on styles or pathways which were individual and cultural preferences rather than state's supports.

\section{MULTIDIMENSIONAL POVERTY SITUATIONS IN THE CENTRAL HIGHLANDS}

The Central Highlands include provinces of Lam Dong, Dak Nong, Dak Lak, Gia Lai and Kon Tum. The Central Highlands are the cradle of Gong culture, an intangible world cultural heritage recognised by the UNESCO in 2005 .

The Central Highlands currently had $21.8 \%$ of poor households of the total poor ethnic minority households of the country. Rural areas had twice as many poor households compared to urban areas, $22.7 \%$ compared to $11.7 \%$. Of the provinces in the Central Highlands, Dak Nong, Gia Lai and Kon Tum were the three provinces with the highest poverty rate, nearly $28 \%$ in the region. Lam Dong province had the lowest rate of poor ethnic minority households with about $6.6 \%$.

The above results are consistent with many previous studies that are poverty in Vietnam largely concentrated in rural area, and ethnic minorities.

The average income of ethnic minorities in the Central Highlands was about $\$ 1.50$ US per person per day. This average was higher than the Vietnamese government's regulation, and met the requirement of MDG 2030 (less than \$1.25 US per person per day.)

Among indigenous peoples in the Central Highlands, the Sedang people had the lowest income, about \$29.55 US, compared with the Brau people, about \$56.35 US (Table 1). Thus, the difference between the highest and lowest ethnic group was two times.

In the education indicator, the highest percentage of households with members over 15 years of age who did not graduate from lower secondary school was the Jarai people $(50.30 \%)$, the lowest was the Gie-Trieng people $(27.60 \%)$. For ethnic groups with a non-attendance rate between 5 and 15 years, the Jarai people had the highest rate $(17.40 \%)$, and the lowest was the Gie-Trieng people $(4.40 \%)$ (Table 1.)

In the health indicator, the highest proportion of households with members aged 6 and older without health insurance is Ede $(36.50 \%)$, the lowest is Brau $(2.40 \%)$. Thus, this result showed that, although the Vietnamese government had a policy to provide free health insurance for all ethnic minorities, particularly children. However, the results of this study showed that there was a difference between policy and current practice in Vietnam for ethnic minorities in the Central Highlands (Table 1.)

In housing issues, the research results showed that there were differences in the quality of houses (solid, semi-permanent, simple) and living area per capita (less than $8 \mathrm{~m}^{2}$ per person). The Brau people have the lowest percentage with quality housing $(20.00 \%)$, but they have the highest rate in living area per capita $(8.80 \%)$. The Bahnar people have the highest percentage of quality housing in the Central Highlands (39.10\%) (Table 1.)

Access to clean water and owning a toilet are important indicators of measuring living conditions. The survey results showed that many Sedang households had the least access to clean water (48.90\%) among ethnic minorities. The Bahnar people had the highest rate of households without toilets $(45.82 \%)$. The Ro Mam households had access to the cleanest water, while the Gie-Trieng people had the most households with owning toilet (Table 1.)

In access to information of ethnic minorities in the Central Highlands, the Brau people had the highest rate in less telephone by households $(82.60 \%)$. Households of this ethnic group also had the second highest rate, only after Sedang $(35.50 \%)$, when they were unable to own television $(26.40 \%)$ (Table 1.) 
Other ethnic groups like Ede (26.20\%), Co Ho (10.40\%) etc. were the most conditional people in accessing information. The Ro Mam people had the highest rate of households owning television (94\%), but they had few phone owners (29\%) (Table 1.)

Thus, the research results showed that among indigenous ethnic minorities in the Central Highlands, there were differences in indicators of multi-dimensional poverty measurement. The Brau people had the highest income, but the indicators for education, housing, living conditions and access to information were quite poor compared to other ethnic groups. The Sedang people had the lowest income, but indicators of child education and health insurance were very good compared to other ethnic groups. Differences lead to unstainable development in the indigenous ethnic minorities in the Central Highlands, Vietnam. Therefore, the Vietnamese government needs to have an inclusive policy to overcome poverty reduction in the following years.

\section{MULTIDIMENSIONAL POVERTY IN THE JARAI PEOPLE}

\section{a) Background of the Ia Glai community}

Changes in the Jarai people in the Ia Glai community originated before 1986 (Doi Moi policy). In 1985, according to the government's policy, a large amount of commune forest land, about 50 hectares, was reclaimed to be transferred to the Chu Se Rubber Company. Until now, there are some houses built by the company to compensate people in the process of land acquisition. Development status of the Ia Glai commune is a process that lasted for more than 30 years. Before 1986, the commune's population only fluctuated around 2,000 people (about $70 \%$ were Jarai people.) In the period after 1996, 10 years after Doi Moi (1986), the population has nearly doubled. In every 10 years, the number of immigrants continues to increase with nearly 1,000 people. In 2006, the People's Committee of the Ia Glai community has decided to increase an administrative unit in 2006 with an additional village due to the large number of Kinh (Vietnamese) immigrants. By 2016, the total population of Ia Glai community was 6.120 persons in 1.340 households, of which the proportion of Kinh people accounts for $56.47 \%$. The increase in large numbers of immigrants came from world economic integration (World Trade Organization for example), exporting of crop products such as coffee and pepper. It is noted that Vietnam is one of the leading countries in the world in exporting these products.

The economic structure in the Ia Glai community has also changed since 1986. In 1986, the main crop in the community was food crops (rice, maize, sweet potato, cassava, etc.) and industrial crops (peanuts, sugarcane, etc.) In this year, the area for growing food crops was more than 203 hectares, four times more than the area of industrial crops (46 hectares). However, until 2018, the land area for industrial crops (coffee, pepper ...) was more than 1,000 hectares compared to the whole rice area of 120 hectares. Thus, in over 30 years, the land structure in Ia Glai community has had important changes, from the land area mainly cultivating food crops to industrial crops, from low-value crops to high value plants for exporting (Nong 2017.)

\section{b) Multidimensional Poverty of the Jarai People}

There was a huge difference between group 1 (lowest income group) and group 5 (highest income group.) In the lowest income group, an average of 1 person per year earned over 2 million Vietnam Dong per person per year (about $\$ 86.43$ US.) In the highest income group, an average of a person earned more than 25 million Vietnam Dong per person per year (about $\$ 1,080.38$ US). The income gap between these two groups was more than 12.5 times.

Therefore, we can see an inequality in income in the Jarai people. The reasons for the differences were that the better-off households were young families, higher education, less people per family (4-5 persons), more farmland, and having many high value crops such as coffee, pepper etc.

As for the group with the lowest income, through in-depth interviews and group discussions, many people argued that in over the last three years they were in the worst income years because of climate change. This phenomenon reduced rice's and coffee's output. Not only that, pepper trees, main agriculture in the community, got "yellow leaf" disease, and people could not find effective medicine to cure.

According to official reports from local government, in recent years, due to the impact of climate change, the cultivation of rice and its output were not good as the set targets. The main reason was drought or excessive rain in different years. For example, in 2011, the total rice production reached only 259 tons, reaching $53.9 \%$ of the plan. In 2012 , due to excessive rainfall, 7.1 hectare of rice land was completely damaged. Therefore, output of rice in 2012 was only $89.7 \%$ compared to the plan. In 2015 as well, the rice's output only achieved $81.8 \%$ of the plan.

In addition, reports of local government mentioned some other causes that effected to rice's output such as rats, insects, etc. (Ia Glai Commune People's Committee (2011-2018.) In an in-depth interview with the chairman of the People's Committee of Ia Glai, he also argued that in many years, the local government had to extract at least 10 million VND (about $\$ 430.66$ US) to buy rice and gave it to hungry people. The statistics we have collected also show that, although the people in this village grow two crops per year, the harvest output was very low compared to the previous years. Many households believed that this year they reduced their production by a quarter compared with previous years. By analyzing the data collected by the research team, more than $83 \%$ of people said that rice production this year decreased compared to previous years. The main reason many people mention was due to lack of irrigation water.

In addition to the severe decline in rice production, pepper and coffee in recent years also declined in production. The results of our study found that $70 \%$ of households were declined in output compared to previous years.

Based on the data we collected, one household could get an average of $1,483 \mathrm{~kg}$ of coffee, and $11,095 \mathrm{~kg}$ of pepper in 2015 . Over $70 \%$ of Jarai people believed that production was confined compared to many years ago.

In the research site, we also compared coffee production between Kinh (Vietnamese) people to Jarai people. For example, Ms. Tha's family (Jarai people) had $7,000 \mathrm{~m}^{2}$ of coffee land, in 2016, her household only harvested $1,500 \mathrm{~kg}$, much less than Mr. Nho's house (Kinh people) who had area for planting only $6,000 \mathrm{~m}^{2}$, but

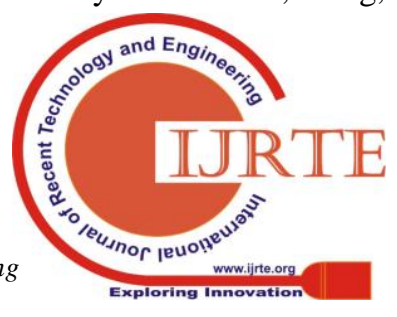


harvested more than $2,500 \mathrm{~kg}$ of coffee. On average, Ms. Tha's household only harvested over $214 \mathrm{~kg}$ per $1,000 \mathrm{~m}^{2}$ compared to Mr. Nho's household, $416 \mathrm{~kg}$ per $1,000 \mathrm{~m}^{2}$.

Therefore, due to unbalanced income, many Jarai households had to borrow money from different banks or borrow from lenders with high interest rates. In our research, there were more than $90 \%$ of Jarai households that did not save money from agricultural activities in over the last two years.

Poverty affected to another very important challenge: access to capital. At interviews with officials of Ia Glai community, they argued that the poor could only borrow from five to ten million VND at the Social Policy bank (state bank) with lower interest rate, $1.2 \%$ per year. In case Jarai households wanted to borrow more, they had to borrow money at commercial banks with higher interest rate, about $12 \%$ per year, and they had to mortgage their house or land to get money for their farming. This condition was not popular to many Jarai households due to document processing. In general, one Jarai household could not get enough money (five to ten million VND) for planting. Therefore, they had to get money from different resources. For example, they could loan money, fertilizer, or pesticide from household enterprises running by Kinh people. Meanwhile, they had a commitment to sell coffee and pepper to these household enterprises at end of the harvest season.

In addition to changing weather, prices of coffee and especially pepper also fluctuates seriously. If before 2015, the price of coffee fluctuated $35,000 \mathrm{VND}$ (\$1.51 US) for $1 \mathrm{~kg}$, pepper for 150,000 VND ( $\$ 6.48 \mathrm{US}$ ) for $1 \mathrm{~kg}$, then from 2016 onwards it had been seriously reduced. Until 2018, the price of coffee was only about 30,000 VND (\$1.30 US), while the pepper price decreased dramatically 50,000 VND $(\$ 2.16$ US).

Among other criteria for multidimensional poverty, the research results showed that:

In terms of health issue, awareness of the use of health insurance services for Jarai children took much time to propagate the benefits of insurance. Survey results showed that only $24.00 \%$ of people had health insurance, the remaining $76.00 \%$ of people did not know or did not have health insurance (Figure 1.) This showed that although the state mandates that children had prescribed health insurance, or ethnic minority children had priority policies in health insurance; however, the awareness of people in this issue was not high in the Jarai people.

Regarding education issue, the research showed that, school-aged children ensured good achievements, but the learning conditions (schools and learning equipment) were still very poor compared to school conditions in central Gia Lai province. The proportion of people who had not attended school, who did not know how to read and write was still quite high in the survey group with the rate of $24.57 \%$. The proportion of people who only reached primary education also accounted for over $40.00 \%$ (Figure 2.) This showed that the social environment (through parents and the elderly) was not harmonized with the social environment (through policies and incentives from the state to encourage learning); and there was no fairness in state policies, study conditions among regions in the Central Highlands, in particular between rural and urban areas, between ethnic minority communities and Kinh (Vietnamese) people.

Among the multidimensional poverty issues in the Jarai community in Ia Glai, clean water was the most important issue for people. For many years, under the influence of climate change, drought had affected the lives of many people here. During the fieldwork in the summer of 2016, natural water supplies for many communities were exhausted. To overcome that situation, people began to shift to drilling deeper wells. For example, in previous years, a well was only 15 meters deep, but this would have to be 25 or 30 meters in recent years. Therefore, multidimensional poverty of the Jarai people in the Central Highlands was having certain gaps regarding government report and our research.

\section{CONCLUSION}

First of all, the research results showed that multidimensional poverty had different results in the indigenous ethnic minorities in the Central Highlands, Vietnam. Moreover, ethnic minorities in the Central Highlands were different from each other in indicators of multidimensional poverty, and it was difficult to determine how poor they were. The main cause was each ethnic group had different strengths and weaknesses.

Secondly, based on preliminary fieldwork, research results showed differences about perceptions like health and education among ethnic people. Therefore, we could see a gap between governmnet policy and awareness of people, in particular those who had less education.

Thirdly, compared to government report, the results of our study found that multidimensional poverty was also different. The report only gave a good figure through the data, but the fact that multidimensional poverty relied heavily on social security, such as education, health care, and agricultural knowledge.

Finally, from policy to reality, measuring multidimensional poverty was more difficult than income poverty. Issues related to social security were volatile, even income fluctuates over time. In addition to factors such as policy and people, the natural environment, such as climate change, became a variable that played an important role in influencing people's living conditions. Therefore, sustainable development of indigenous ethnic minorities needs to put more effort in both policies from government and people by themselves.

\section{REFERENCES}

1. Baulch, B., Truong, C. T. K., Haughton, D., \& Haughton, J. (2002), Ethnic minority development in Vietnam: A socio-economic perspective, Working Paper 2836, Washington, D.C.: World Bank.

2. Bui, A. T., Nguyen, C. V. \& Pham, T. H. (2017). Poverty among ethnic minorities: The transition process, inequality and economic growth. Applied Economics, 49, 3114-3128.

3. Committee for Ethnic Minority Affairs (2016). Results of survey of socio-economic status of 53 ethnic minorities in 2015. [Online] Available:

http://cema.gov.vn/ket-qua-dieu-tra-thuc-trang-kt-xh-53-dan-toc-thie u-so-nam-2015.htm (July 10, 2017)

4. Dournes, J. (2018). Potao: A Theory about power of the Jarai people in Indochina (Vietnamese translation). Hanoi: World Publishing House.

5. Ia Glai Commune People's Committee (2011-2018). Reports on the implementation status of annual socio-economic indicators. Gia Lai province.

6. Haughton, J. (2001). Introduction: Extraordinary changes. In: D. Haughton, J. Haughton, \& P. Nguyen (Eds.), Living standards during an economic boom: The case of Vietnam (pp. 9-32). Hanoi: Statistics Publishing House. 
7. Nooteboom, G. (2015). Forgotten People: Poverty, Risk and Social Security in Indonesia: The case of the Madurese. Boston: BRILL.

8. Nong, B. N. (2017). The Livelihood transformation of Gia-rai people in Ia Glai commune, Chu Se district, Gia Lai province since the Renovation (1986) up to Present. Anthropology Review, 6, 61-67.

9. Nong, B. N. (2018). Jarai people. In: T. X. Vuong (ed.), Ethnic minorities in Vietnam (4 ${ }^{\text {th }}$ volume) (pp. 239-306). Hanoi: National Political Publishing House.

10. Pimhidzai, O. (2018). Climbing the ladder: Poverty reduction and shared prosperity in Vietnam. Washington, D.C.: World Bank.

11. Prime Minister of Vietnam (2018). Vietnam's voluntary national review on the implementation of the sustainable development goals. Hanoi.
12. Prime Minister of Vietnam (2015). Decision No.59/2015/QD-TTG about promulgating multidimensional poverty levels applicable during 2016-2020. Hanoi.

13. Phung, D. T., Nguyen, C. V., Nguyen, C. T., Nguyen, T. Nh. \& Ta, Th. Kh. V. (2016). Ethnic minorities and sustainable development goals: Who will be left behind? Hanoi: Mekong Development Research Institute.

14. Socialist Republic of Vietnam (2002). Comprehensive strategy for growth and poverty reduction. Hanoi: Authority of Publication, Printing and Distribution.

15. Van de Walle, D., \& Gunewardena, D. (2001). Sources of ethnic inequality in Vietnam. Journal of Development Economics, 65, 177-207.

Table 1. Multidimensional poverty of ethnic minorities in the Central Highlands

Unit: Percent $(\%)$

\begin{tabular}{|c|c|c|c|c|c|c|c|c|c|c|}
\hline \multirow[t]{2}{*}{ People } & \multirow{2}{*}{$\begin{array}{l}\text { Monthly } \\
\text { income } \\
\text { per } \\
\text { capital } \\
(1,000 \\
\text { VND)* }\end{array}$} & \multicolumn{2}{|l|}{ Education } & \multirow{2}{*}{$\begin{array}{l}\text { Healthcare } \\
\begin{array}{l}\text { Health } \\
\text { insurance }\end{array}\end{array}$} & \multicolumn{2}{|l|}{ House } & \multicolumn{2}{|c|}{ Living conditions } & \multicolumn{2}{|c|}{ Access to information } \\
\hline & & $\begin{array}{l}\text { Adult's } \\
\text { education } \\
\text { level }\end{array}$ & $\begin{array}{l}\text { Child's } \\
\text { school } \\
\text { attendance }\end{array}$ & & $\begin{array}{l}\text { Housing } \\
\text { quality }\end{array}$ & $\begin{array}{l}\text { Living } \\
\text { area per } \\
\text { capita }\end{array}$ & $\begin{array}{l}\text { Water for } \\
\text { daily } \\
\text { activities }\end{array}$ & Toilet & $\begin{array}{l}\text { Telecommu } \\
\text { nication } \\
\text { services }\end{array}$ & $\begin{array}{l}\text { Telecommun } \\
\text { ication } \\
\text { equipment }\end{array}$ \\
\hline Bahnar & 856.90 & 47.30 & 14.30 & 17.30 & 11.90 & 39.10 & 24.30 & 45.82 & 52.20 & 21.40 \\
\hline Brau & $1,310.70$ & 43.20 & 12.00 & 2.40 & 20.00 & 8.80 & 38.40 & 28.47 & 82.60 & 26.40 \\
\hline Churu & $1,127.10$ & 46.20 & 10.90 & 11.80 & 7.60 & 26.00 & 29.40 & 28.26 & 51.60 & 12.30 \\
\hline $\mathrm{Co} \mathrm{Ho}$ & $1,093.10$ & 43.10 & 11.10 & 27.20 & 9.30 & 31.40 & 13.20 & 25.94 & 34.90 & 10.40 \\
\hline Ede & $1,124.20$ & 43.40 & 8.40 & 36.50 & 19.00 & 25.10 & 18.80 & 22.14 & 26.20 & 11.00 \\
\hline Jarai & 941.30 & 50.30 & 17.40 & 28.20 & 14.70 & 30.60 & 29.40 & 43.93 & 42.40 & 16.00 \\
\hline Mnong & 802.00 & 46.90 & 14.30 & 14.60 & 19.80 & 29.50 & 35.00 & 36.30 & 44.10 & 20.80 \\
\hline $\begin{array}{l}\text { Gie-Trien } \\
\mathrm{g}\end{array}$ & 770.20 & 27.60 & 4.40 & 3.30 & 9.80 & 17.80 & 29.50 & 10.68 & 45.20 & 19.60 \\
\hline Ro Mam & 773.90 & 29.70 & 5.90 & 17.80 & 8.80 & 9.90 & 1.00 & 15.79 & 71.00 & 5.90 \\
\hline Sedang & 687.30 & 36.50 & 6.10 & 5.60 & 16.30 & 32.40 & 48.90 & 25.25 & 61.10 & 35.50 \\
\hline
\end{tabular}

$* \$ 1 \mathrm{US}=23,200 \mathrm{VND}$

Note: Author calculated based on statistics of the Committee for Ethnic Minority Affairs and Phung, D. T. et al. (2016)

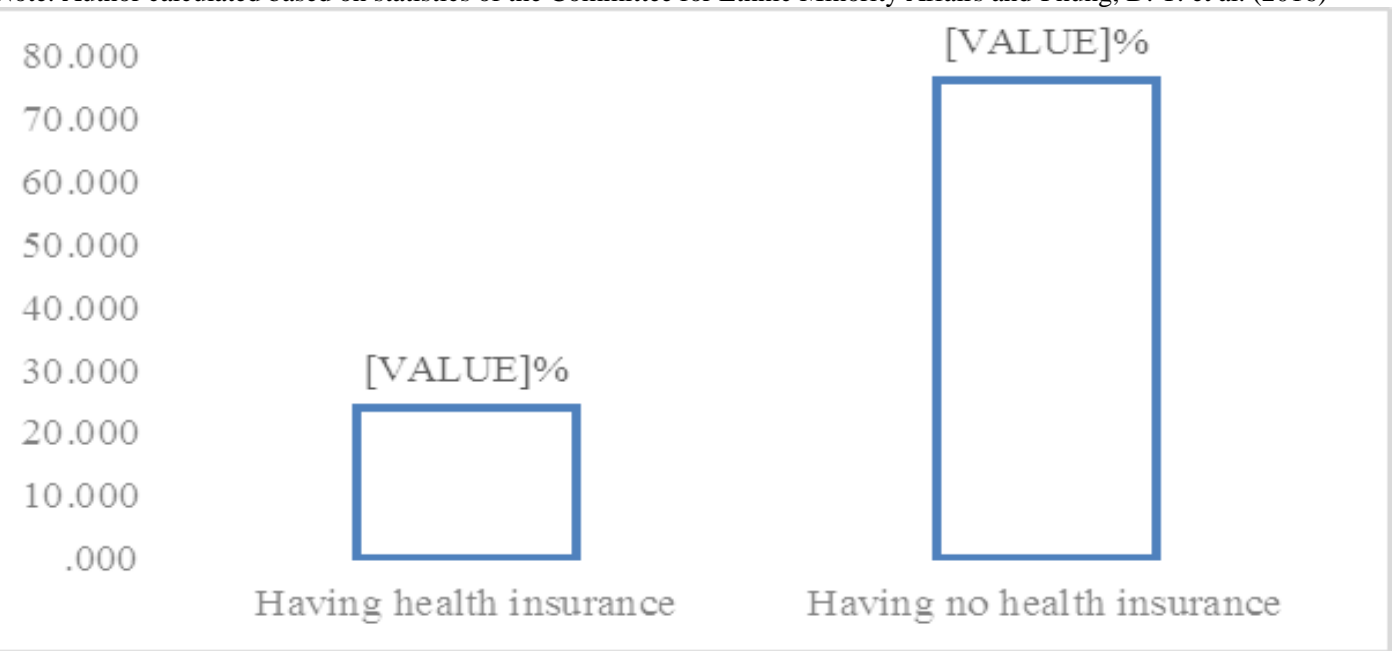

Figure 1. The level of participation in health insurance by household members 


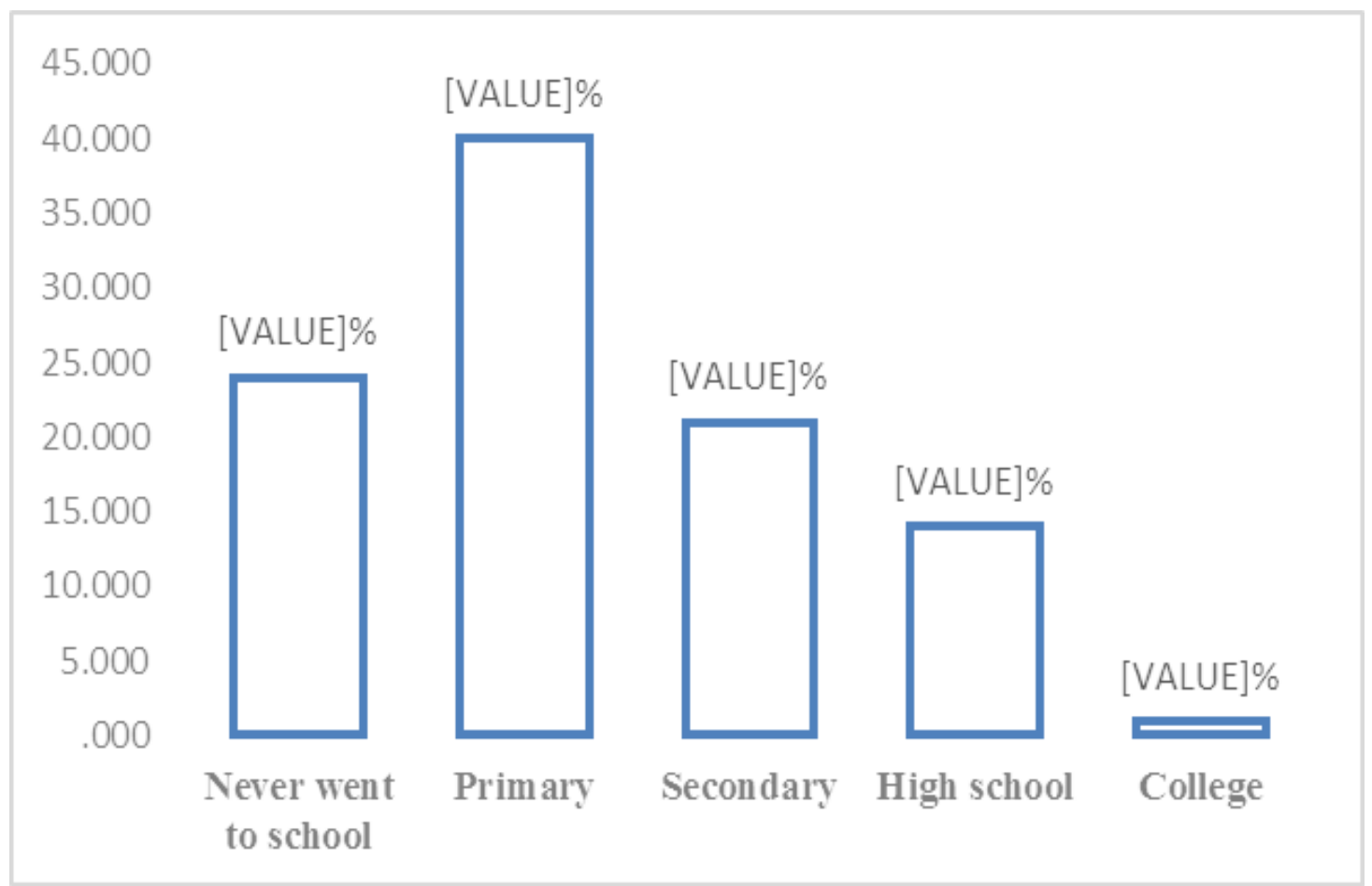

Figure 2. Education level of the Jarai people in the Ia Glai community

\section{Author Profile:}

Nguyen Bang Nong, MA in anthropology, publications in ethnic minority people in Vietnam, including (2018) "Jarai People" in Ethnicity in Vietnam: Malayo-Polynesian Language Group (Volume 4), Vuong Xuan Tinh (editor). National Political Publishing House, Hanoi, Vietnam, pp. 237-306; (2018) "Chu-ru People" in Ethnicity in Vietnam: Malayo-Polynesian Language Group (Volume 4), Vuong Xuan Tinh (editor). National Political Publishing House, Hanoi, Vietnam, pp. 564-628; (2017.) "Changing of Jarai economics in Ia Glai, Chuse, Gia Lai since Doi Moi (1986) to now." Anthropological Review 6: 61-67; (2017.) "Gie-Trieng People” in Ethnicity in Vietnam: Mon-Khmer Language Group (Volume 3), Vuong Xuan Tinh (editor). National Political Publishing House, Hanoi, Vietnam, pp. 602-639; (2017.) "Ma People" in Ethnicity in Vietnam: Mon-Khmer Language Group (Volume 3), Vuong Xuan Tinh (editor). National Political Publishing House, Hanoi, Vietnam, pp. 644-707; (2015) "Social capital of the poor in Hanoi city." Hanoi Social Science and Technology Review 6: 1-18. Nguyen Bang Nong, the author is interested in indigenous ethnic minority people in Vietnam, particularly in the Central Highlands with subjects such as land, deforestation, social change, and household economics. 